\title{
Computational analysis by molecular docking of thirty alkaloid compounds from medicinal plants as potent inhibitors of SARS-CoV-2 main protease
}

Tunga Kuhana A. ( $\nabla$ tunga_tunga@yahoo.frFR)

University of Kinshasa

Jason T. Kilembe

University of Kinshasa

Aristote Matondo

University of Kinshasa

Khamis M. Yussuf

Zhengzhou University

Lauraine Nininahazwe

Zhengzhou University

Fils K. Nkatu

University of Kinshasa

Milka N. Tshingamb

University of Kinshasa

Emmanuel K. Vangu

University of Kinshasa

Junior T. Kindala

University of Kinshasa

Shetonde 0. Mihigo

University of Kinshasa

Sungula J. Kayembe

University of Kinshasa

Yves S. Kafuti

University of Kinshasa

Agboyibor Clement

Zhengzhou University

Kalulu M. Taba

University of Kinshasa

Research Article 
Keywords: COVID-19, medicinal plants, binding affinity, ADMET properties, molecular docking

Posted Date: October 20th, 2020

DOI: https://doi.org/10.21203/rs.3.rs-94752/v1

License: (c) (1) This work is licensed under a Creative Commons Attribution 4.0 International License. Read Full License 


\section{Abstract}

2020 has been highly affected by the COVID-19 outbreak. The urgent needs for a potent and effective drug for treatment of this malignance put pressure on researchers and scientists worldwide to develop potential drug or a vaccine to resist SARS-CoV-2. We report in this paper the assessment of the efficiency of thirty alkaloid compounds derived from African medicinal plants against the SARS-CoV-2 main protease through molecular docking and bioinformatics approaches. The results reveal four potential inhibitors (ligands 18, 21, 23 and 24) with the highest binding energies up to $12.26 \mathrm{kcal} / \mathrm{mol}$ with good profile of ADMET, as well as fully obey the Lipinski's rule of five.

\section{Introduction}

The coronaviruses have recently become a serious problem in the world. It is family of coronavirinae which contains four genera based on genetic properties: alpha coronavirus, delta coronavirus, gamma coronavirus and beta coronavirus. Approximately, the genome size of coronavirus compare to other RNA viruses range from 26 to 32 kilobases. The Severe Acute Respiratory Syndrome Coronavirus (SARS-CoV) and the Middle East Respiratory Syndrome Coronavirus (MERS-CoV) also belong to the beta coronavirus genus and are zootopic pathogens that can cause severe respiratory diseases in humans $[1,2]$.

The novel coronavirus pneumonia (coronavirus disease 2019, COVID-19 or SARS-CoV-2) is a highly contagious acute respiratory infectious disease and constitutes a major public health problem. In fact, the nucleic acid of the novel coronavirus is a positive-stranded RNA [3]. Its structural proteins include: spike protein $(S)$, envelope protein $(E)$, membrane protein $(M)$, and nucleocapsid phosphoprotein; while its transcribed non-structural proteins include: ORF1ab, ORF3a, ORF6, ORF7a, ORF10 and ORF8.

The novel coronavirus is highly homologous to the coronavirus in bats [4,5], and has significant homology with SARS virus [6-8]. It was first detected in December 2019 in Wuhan, Hubei Province (China), and became a global pandemic, killing hundreds of thousands of people [9]. The infected patients by SARS-CoV-2 have a fever and the temperature above $38^{\circ} \mathrm{C}$ with symptoms such as dry cough, fatigue, dyspnea, difficulty breathing, and various fatal complications including organ failure, septic shock, pulmonary edema, severe pneumonia, and Acute Respiratory Distress Syndrome (ARDS) and frost- glasslike symptoms in the lungs [10].

There are only two ways of transmission of COVID-19 that have been reported, by droplets and contact (direct and indirect) [11].

Currently, there are no specialized treatments available for COVID-19 and several explorations relevant to the therapies of COVID-19 are becoming inadequate [12]. Consequently, other than vaccine development, academics and researchers have undertook several strategies, by using on one hand traditional medicinal plants as possible alleviating drugs [13-14], and one the other hand by exploring in silico studies in order 
to pinpoint potential inhibitors from a set of secondary metabolites and other chemical compounds [1516]. Nevertheless, it is worthy to mention that some studies have encountered the combinations of existing drug candidates (FDA approved drugs) involving anti-HIV drugs such as lopinavir/ritonavir, remdesivir, etc for therapeutic use against COVID-19 [17].

The recognition of protease as an attractive target to inhibit COVID-19 replication has emerged as an interesting pathway to investigate both natural and synthetic drugs to target the viral protease $[\mathbf{1 8 , 1 9 ]}$.

Medicinal plants provide a wide variety of integral and alternative drugs which may assist to solve the many puzzles behind several viral diseases [20]. So, the different part of plant (stem, roots, seed, bark, food and flower) are used in treating disease vary from frequent to rare infectious and non-infectious ailments [21].

In this study, we evaluated the potential inhibitors of SARS-CoV-2 main protease by thirty alkaloid compounds derived from African medicinal plants as one of rich in floral biodiversity and its plant materials are endowed with natural products (NPs) with intriguing chemical structures and promising biological activities which can be used in searching the solution against COVID-19 [22]. According to the World Health Organization (WHO), more than $80 \%$ of the population in Africa use traditional medicine to solve their primary health problem [9]. A survey of literature allowed us to identify 30 alkaloids compounds derived from plants used in African Traditional Medicine (ATM), harvested from the following countries: Republic of the Congo, Nigeria, Tanzania, South Africa, Ivory Coast West African countries, Kenya and East African countries (Table 1) [22]. These 30 phytochemicals have been put in interaction with the SARS-CoV-2 main protease in order to assess their efficiency against the virus protease using molecular docking tool, and thus pinpoint the potential inhibitors.

Table 1 Summary of selected alkaloids derived from the African plant: indoles and naphthoisoquinolines 


\begin{tabular}{|c|c|c|c|c|c|}
\hline Compound subclass & $\begin{array}{l}\text { Isolated } \\
\text { metabolites }\end{array}$ & $\begin{array}{l}\text { Plant species } \\
\text { (family) }\end{array}$ & $\begin{array}{l}\text { Part of } \\
\text { plant } \\
\text { studied }\end{array}$ & $\begin{array}{l}\text { Harvest } \\
\text { place } \\
\text { (locality, } \\
\text { country) }\end{array}$ & Reference \\
\hline \multirow[t]{8}{*}{ Indole alkaloids } & $\begin{array}{l}1,2,3,4,5 \\
6\end{array}$ & $\begin{array}{l}\text { Monodora } \\
\text { angolensis } \\
\text { (Annonaceae) }\end{array}$ & $\begin{array}{l}\text { Stem } \\
\text { and } \\
\text { root } \\
\text { bark }\end{array}$ & $\begin{array}{l}\text { Kiwanda, } \\
\text { Tanzania }\end{array}$ & [23] \\
\hline & 7,8 & $\begin{array}{l}\text { Isolona cauliflora } \\
\text { (Annonaceae) }\end{array}$ & $\begin{array}{l}\text { Stem } \\
\text { and } \\
\text { root }\end{array}$ & $\begin{array}{l}\text { Namikwe } \\
\text { Island, }\end{array}$ & [23] \\
\hline & & & $\begin{array}{l}\text { bark, } \\
\text { and } \\
\text { flower } \\
\text { stalks }\end{array}$ & Tanzania & \\
\hline & 9 & $\begin{array}{l}\text { strychnos } \\
\text { usambarensis } \\
\text { (loganiaceae) }\end{array}$ & leaves & $\begin{array}{l}\text { Akagera } \\
\text { National } \\
\text { park,Rwanda }\end{array}$ & [24] \\
\hline & 10 and 11 & $\begin{array}{l}\text { Penianthus } \\
\text { longifolius } \\
\text { (Menispermacea) }\end{array}$ & $\begin{array}{l}\text { Stem } \\
\text { bark }\end{array}$ & Cameroon & [25] \\
\hline & 12 & $\begin{array}{l}\text { Fagara } \\
\text { zanthoxyloides } \\
\text { (Rutaceae) }\end{array}$ & roots & Nigeria & [26] \\
\hline & 13 & $\begin{array}{l}\text { Picralima nitida } \\
\text { (Apcynaceae) }\end{array}$ & fruits & $\begin{array}{l}\text { Nnewi, } \\
\text { Nigeria }\end{array}$ & [27] \\
\hline & 14 and 15 & $\begin{array}{l}\text { Strychnos } \\
\text { usambarensis } \\
\text { (loganiaceae) }\end{array}$ & leave & $\begin{array}{l}\text { Akagera } \\
\text { National } \\
\text { park, } \\
\text { Rwanda }\end{array}$ & [28] \\
\hline \multirow[t]{4}{*}{ Naphthoisoquinolines } & $\begin{array}{l}\text { 16, 17, } \\
18,19 \text { and } \\
20\end{array}$ & $\begin{array}{l}\text { Ancistrocladus } \\
\text { robertsoniorum } \\
\text { (Acistrocladaceae) }\end{array}$ & $\begin{array}{l}\text { Stems } \\
\text { and } \\
\text { leaves }\end{array}$ & $\begin{array}{l}\text { Buda } \\
\text { Mafisini } \\
\text { Forest, } \\
\text { Kenya }\end{array}$ & [29] \\
\hline & $\begin{array}{l}21,22,23 \\
\text { and } 24\end{array}$ & $\begin{array}{l}\text { Ancistrocladus } \\
\text { tanzaniensis } \\
\text { (Acistrocladaceae) }\end{array}$ & leaves & $\begin{array}{l}\text { Uzungwa } \\
\text { Mountains, } \\
\text { Tanzania }\end{array}$ & [30] \\
\hline & 25 & $\begin{array}{l}\text { Triphyophyllum } \\
\text { peltatum } \\
\text { (Dioncophyllaceae) }\end{array}$ & roots & $\begin{array}{l}\text { Parc de Taï, } \\
\text { West Ivory } \\
\text { Coast }\end{array}$ & [31] \\
\hline & 26 & $\begin{array}{l}\text { Triphyophyllum } \\
\text { peltatum } \\
\text { (Dioncophyllaceae) }\end{array}$ & $\begin{array}{l}\text { Root } \\
\text { bark }\end{array}$ & $\begin{array}{l}\text { West Ivory } \\
\text { Coast }\end{array}$ & [32] \\
\hline
\end{tabular}




\section{7, 28, 29 Triphyophyllum Leaves Mt. and 30 peltatum and Nabemba, (Dioncophyllaceae) Congo Twigs \\ Republica and West Ivory Coast}

$[33,34]$

\section{Materials And Methods}

\subsection{Receptor preparation}

The crystal structure of COVID-19 Mpro (PDB ID: 6LU7) (Figure 1) was retrieved from the Protein Data Bank and imported into Auto dock 4.2 where the inhibitor and water molecules were removed before the docking and hydrogen atoms were added to the protein in order to correct the ionization and tautomeric states of the amino acid residues. Further, Kollman charges were added and the protein was saved in .pdbqt format [35].

\subsection{Ligands preparation and pharmacokinetic study}

The selected alkaloid compounds derived from African medicinal plant were drawn using ChemDraw Ultra (8.0). Figures 2 and 3 show the 2D structures of the sketched compounds. From ChemDraw 2D the ligands were imported to obtain 3D structures. The 3D ligands were then saved in .pdb format for molecular docking with the SARS-CoV-2 main protease.

Since the binding affinity of ligand-protein interactions merely gives an idea of the thermodynamic stability of the formed complex, it is important to analyze the pharmacodynamics of the potential inhibitors. To do so, predictions of ADMET (Adsorption, Distribution, Metabolism, Excretion and Toxicity) of all investigated compounds were assessed by means of SwissADME database available at https://www.swissadme.ch, and preADMET server (Korea) [36, 37].

\subsubsection{Molecular recognition ligand-protein by molecular docking}

Molecular docking is used to estimate the scoring function and evaluate protein-ligand interactions in order to predict the binding affinity and activity of the ligand molecule [38]. Autodock tool was used to generate the bioactive binding poses of ligands dataset in the active site of SARS-CoV-2 Mpro. The protein coordinates from the bound ligand of $6 \mathrm{LU7}$ was used to define the binding site. So, scoring function was calculated using the standard protocol of Lamarckian genetic algorithm [39]. The grid map for docking calculations was centered on the target protein. Accelrys Discovery Studio 2019 software [40] was used to model non-bonded polar and hydrophobic contacts in the inhibitor site of 6LU7. The docking results were visualized using Pymol 2.3.4.0 (see Figures S1 and S2 in supplementary data) and Discovery Studio Visualizer 4.0. 


\section{Result And Discussion}

\subsection{Energetics and ligands-protein interactions}

The docking calculations of thirty alkaloid compounds with SARS-CoV-2 protease were carried out by using Autodock virtual screening tool. The results of docking calculations in terms of binding affinity $(\mathrm{kcal} / \mathrm{mol})$ and interactions of different orientations of alkaloid compounds in the active site of the SARSCoV-2 main protease are shown in Table 2. Also gathered in this table are the drug-likeness properties of the ligands.

The binding affinity values of the virtual screening between the 30 selected compounds and the SARSCoV-2 main protease range from 5.52 to $12.26 \mathrm{kcal} / \mathrm{mol}$. It should be noted that the best candidate against COVID-19 is a compound (a hit molecule) that binds to the target (SARS-CoV-2 main protease) and has the desired effect, in addition to form a stable complex. Thermodynamically, this is a compound with the highest possible binding energy expressed in terms of Gibbs free energy variation $(\Delta G)[9,15]$. This allows us to identify in this initial step 22 hits mainly: ligand $2(7.49 \mathrm{kcal} / \mathrm{mol})$, from ligand $8(7.88$ $\mathrm{kcal} / \mathrm{mol})$ to ligand $12(8.17 \mathrm{kcal} / \mathrm{mol})$, from ligand $14(9.73 \mathrm{kcal} / \mathrm{mol})$ to ligand $28(10.70 \mathrm{kcal} / \mathrm{mol})$, and ligand $30(7.81 \mathrm{kcal} / \mathrm{mol})$. These ligands were retained in comparison of their binding affinity with those reported in this paper of the FDA approved drugs used to treat erectile dysfunction (tadalafil : 8.80 $\mathrm{kcal} / \mathrm{mol}$ ) and human immunodeficiency virus/HIV (lopinavir : $8.19 \mathrm{kcal} / \mathrm{mol}$ ), as well as in comparison with the binding energy of the reference ligand $(8.80 \mathrm{kcal} / \mathrm{mol})$. The best docked compounds $(\Delta \mathrm{G} \leq 8.2$ $\mathrm{kcal} / \mathrm{mol}$; see also ref. [41] are hits $10(9.33 \mathrm{kcal} / \mathrm{mol}), 11(9.05 \mathrm{kcal} / \mathrm{mol}), 12(8.17 \mathrm{kcal} / \mathrm{mol}), 14(9.73$ $\mathrm{kcal} / \mathrm{mol}), 18(12.26 \mathrm{kcal} / \mathrm{mol}), 21(9.97 \mathrm{kcal} / \mathrm{mol}), 22(9.60 \mathrm{kcal} / \mathrm{mol}), 23(10.99 \mathrm{kcal} / \mathrm{mol}), 24(11.28$ $\mathrm{kcal} / \mathrm{mol}), 25(9.99 \mathrm{kcal} / \mathrm{mol}), 26(8.27 \mathrm{kcal} / \mathrm{mol})$, and $28(10.70 \mathrm{kcal} / \mathrm{mol})$. To the best of our knowledge, this is the first computational study that reports binding energies higher than $10 \mathrm{kcal} / \mathrm{mol}$ of ligands bind to one of the pharmacological targets of the SARS-CoV-2. In fact, Olubiyi and coworkers performed high throughput virtual screening of over one million compounds, but only six with the strongest computed affinities ranging from 8.2 to $8.5 \mathrm{kcal} / \mathrm{mol}$ were identified [41].

The interactions analysis of the 12 best docked ligands can be summarized as follows:

Other than hydrogen bonding interaction which is the main force among non-covalent interactions stabilizing the complexes [42], ligands 10, 11 and 12 show some similarities in interactions involving their aromatic rings. The presence of four aromatic rings in both compounds offer much possibilities to $\pi-\pi$ interactions (stacked and T-shaped) to take place [43]. Other interactions such as $\pi$-alkyl interaction with VAL104, $\pi$-sigma interaction with ILE106, for all three ligands are established; and amide- $\pi$ interaction with ASN151 for ligands 10 and 11 . Ligands 10 and 12 are stabilized only by one hydrogen bonding interaction with GLN107 (ligand 10) and ARG105 (ligand 11) as the interacting residue of the amino acid. With regards to van der Waals (vdW) interactions as one of the main forces, six vdW interactions (GLN110, ARG 105, SER158, ASP153, ILE 152 and PHE8) occur in ligand 10, supported by two hydrogen 
bonds with GLN107 and ILE152 as amino acids residues. Six vdW interactions are also take place in ligand 11 with ARG105, SER158, ASP153, PHE8, PHE294 and GLN110 as AA residues, while seven vdW interactions (PHE 8, ILE 152, ASN151, SER158, GLN107, GLN110, TH111 and ASP295) are identified in the complex ligand 12-Mpro.

Ligand 14 is characterized by one $\mathrm{H}$-bonding interaction with GLN110, $\pi$-alkyl interaction with ILE249 and eleven vdW interactions with ASN203, THR292, ILE106, THR111, PHE 8, ASP295, ASN151, SER158, VAL104, PHE294 and CYS160. Surprisingly, none H-bonding interaction occurs in the ligand 18, albeit the strongest one with highest binding energy $(12.26 \mathrm{kcal} / \mathrm{mol})$. However, this ligand is stabilized by two $\pi-$ alkyl interactions with MET165, CYS145, $\pi-\pi$ interaction with HIS41 and ten vdW interactions with LEU141, GLY143, HIS164, ASP187, TYR54, GLN189, ARG188, THR190, GLN192 and GLU166. This result supports the works from Kasende et al, in which $\pi-\pi$ and vdW interactions are primary forces in stabilizing two polyaromatic macromolecules, even when $\mathrm{H}$-bonding interaction occurs $[43,44]$.

With none $\mathrm{H}$-bonding interaction, except for ligand 22 , one can refer to ligand 18 to understand the stability of ligands $21,22,23$ and 24 with $\Delta G$ values between $10-11 \mathrm{kcal} / \mathrm{mol}$. The complex formed between ligand 25 and the SARS-CoV-2 Mpro is stabilized by three hydrogen bonds with GLU166, CYS145, and HIS163 AA residues; a r-alkyl interaction with MET165 and six vdW interactions with interacting residues GLN192, GLN189, GLY143, ASN142, PHE140, and LEU141.

Finally, the complexes wherein ligands 26 and 28 are involved are stabilized by three (with LYS5, GLN127, LYS137 AA residues) and two hydrogen bonds (CYS145 and HIS163 being the AA residue), respectively. The stability of complex with ligand 26 is supported by a $\pi-\pi$ interaction with TYR126 and six vdW with CYS128, GLY138, GLU290, SER 139, MET6 and VAL125, whereas the stability of complex with ligand 28 is supported by nine vdW interaction with ALA191, GLN189, THR190, GLN192, HIS164, GLY143, ASN142, PHE 140, LEU141.

\subsection{Prediction of pharmacokinetic and toxicity}

In the pipeline of computer-aided drug design, after the identification of hit molecules, the next step to deal with is the pre-clinical optimization that concerns the physicochemical properties, mainly the $\mathrm{ADME} / \mathrm{T}$ prediction. The physicochemical property is an important parameter of a molecule which can be used as a drug and can be predicted by using Lipinski's rule of five (RO5) that is: molecular mass < 500 ; Hydrogen-bond donors (HBD) < 5; Hydrogen-bond acceptors (HBA) < 10; and Log $\mathrm{P}<5$ [45]. Toxicity and pharmacokinetic studies such as absorption, distribution and metabolism of alkaloid compounds were assessed by using the web based application PreADMET (https://preadmet.bmdrc.kr/) and SwissADME database (https://www.swissadme.ch).

The drug-likeness properties accommodated in Lipinski's rule of five of all ligands were calculated and are listed in Table 2. The results reveal that only ligand 14 does not fully obey the Lipinski's rule of five criteria, with only 1 violation (MW 549.75 Da > 500 Da). Consequently, the best 12 docked ligands among the 30 investigated alkaloids may emerge as potential major inhibitors of COVID-19 protease. 
Turning next to the pharmacokinetic and toxicity properties of eleven potential inhibitors ligands, the results displayed in Table 3 reveal that there are potential drug candidates (Table 3 ) among the 12 best docked compounds. First of all, the hit molecule to be tested in clinical phase must be non-carcinogenic. The rodent carcinogenicity in rat predicted by the preADMET server reveals that only ligand 22 is carcinogenic. The Ames test that assesses mutagenicity reveals that 7 ligands are no mutagen, in addition of being no-carcinogenic: ligands $18,21,23,24,25,26$ and 28 . Interestingly, the ligand 18 with highest binding energy is predicted to be no-carcinogenic and no mutagen. The pharmacokinetic evaluation related to inhibition of Cytochrome P450 and substrate of P-glycoprotein shows that ligands 18, 21, 23 and 24 are found to be non-inhibitors of all CYPs. Ligands 10, 11, 12, 22, 25, 26 and 28 inhibit one or two of the cytochromes responsible for drug metabolism (CYP2D6 and CYP3A4), and cannot be presented as potent inhibitors drugs [46]. In the case of the hERG inhibition, all the ligands presented medium risk. Thus, the toxicity prediction shows that the ligands 18, 21, 23 and 24 are safe and represent potential therapeutic candidates against COVID-19.

Table 3 Pharmacokinetics and toxicity properties of the three potential inhibitors.

\begin{tabular}{|c|c|c|c|c|c|c|c|c|c|c|}
\hline Ligand & $\begin{array}{l}\text { Ames- } \\
\text { test }\end{array}$ & $\begin{array}{l}\text { Carcino- } \\
\text { Rat }\end{array}$ & $\begin{array}{l}\text { BBB } \\
\text { p. }\end{array}$ & hERG & $\begin{array}{l}\text { P-gp } \\
\text { S. }\end{array}$ & $1 \mathrm{~A} 2$ & $2 C 19$ & $2 \mathrm{Cg}$ & 2D6 & $3 A 4$ \\
\hline 10 & Mutagen & Negative & Yes & $\begin{array}{l}\text { Medium } \\
\text { risk }\end{array}$ & Yes & No & No & No & Yes & Yes \\
\hline 11 & Mutagen & Negative & Yes & $\begin{array}{l}\text { Medium } \\
\text { risk }\end{array}$ & Yes & Yes & No & No & Yes & Yes \\
\hline 12 & Mutagen & Negative & Yes & $\begin{array}{l}\text { Medium } \\
\text { risk }\end{array}$ & Yes & Yes & Yes & No & Yes & Yes \\
\hline 18 & $\begin{array}{l}\text { No } \\
\text { mutagen }\end{array}$ & Negative & Yes & $\begin{array}{l}\text { Medium } \\
\text { risk }\end{array}$ & Yes & No & No & No & No & No \\
\hline 21 & $\begin{array}{l}\text { No } \\
\text { mutagen }\end{array}$ & Negative & Yes & $\begin{array}{l}\text { Medium } \\
\text { risk }\end{array}$ & Yes & No & No & No & No & No \\
\hline 22 & Mutagen & positive & Yes & $\begin{array}{l}\text { Medium } \\
\text { risk }\end{array}$ & Yes & No & No & Yes & No & Yes \\
\hline 23 & $\begin{array}{l}\text { No } \\
\text { mutagen }\end{array}$ & negative & Yes & $\begin{array}{l}\text { Medium } \\
\text { risk }\end{array}$ & Yes & No & No & No & No & No \\
\hline 24 & $\begin{array}{l}\text { No } \\
\text { mutagen }\end{array}$ & negative & Yes & $\begin{array}{l}\text { Medium } \\
\text { risk }\end{array}$ & Yes & No & No & No & No & No \\
\hline 25 & $\begin{array}{l}\text { No } \\
\text { mutagen }\end{array}$ & negative & Yes & $\begin{array}{l}\text { Medium } \\
\text { risk }\end{array}$ & Yes & No & Yes & No & Yes & Yes \\
\hline 26 & $\begin{array}{l}\text { No } \\
\text { mutagen }\end{array}$ & negative & Yes & $\begin{array}{l}\text { Medium } \\
\text { risk }\end{array}$ & Yes & No & Yes & No & Yes & No \\
\hline 28 & $\begin{array}{l}\text { No } \\
\text { mutagen }\end{array}$ & negative & Yes & $\begin{array}{l}\text { Medium } \\
\text { risk }\end{array}$ & Yes & No & Yes & No & Yes & No \\
\hline
\end{tabular}




\section{Conclusion}

The COVID-19 pandemic continues to spread in the world and most of countries are currently facing the second phase of the virus propagation. Several strategies are used by researchers to help finding a solution to this public health issue. The present study used computational drug design approach by molecular docking to identify potential inhibitors of SARS-CoV-2 main protease from a set of thirty alkaloid compounds from African medicinal plants as potential inhibitors. Scrutiny of the binding affinities leads to 22 hits with highest binding energies, up to $12.26 \mathrm{kcal} / \mathrm{mol}$, but pharmacokinetic investigations as important pre-clinical phase reveal only four compounds as potential therapeutic agents to be used in the treatment of COVID-19: ligands 18, 21, 23 and 24. To the best of our knowledge, this computational study is the first to report binding energies higher than $10 \mathrm{kcal} / \mathrm{mol}$ of ligands bind to one of the pharmacological targets of the SARS-CoV-2. To support this encouraging results, we recommend further in vivo trials for the experimental validation of our findings.

\section{Declarations}

\section{Acknowledgement}

Our sincere thanks go to Professor Kalulu M. Taba for agreeing to supervise this work.

\section{Conflict of interest}

The authors declare that they have no known competing financial interests or personal relationships that could have appeared to influence the work reported in this paper.

All authors read and approved the final manuscript.

\section{Funding}

This study did not receive any particular funding.

\section{References}

1. W. Ji, W. Wang, X. Zhao, J. Zai, X. Li, Homologous recombination within the spike glycoprotein of the newly identified coronavirus may boost cross-species transmission from snake to human. Journal of Medical Virology 92 (2020).

2. N.J. MacLachlan, E.J. Dubovi, in Fenner's Veterinary Virology (Fifth Edition) (eds N. James MacLachlan \& Edward J. Dubovi) (2017) 393-413. 
3. F. Wu et al, A novel coronavirus associated with human respiratory disease in China. Nature (2020) 18.

4. H. Lu, C.W. Stratton, Y.W. Tang, Outbreak of Pneumonia of Unknown Etiology in Wuhan China: the Mystery and the Miracle. Journal of Medical Virology 92 (2020) 401-402.

5. N. Zhu, et al, China Novel Coronavirus Investigating and Research Team. A novel coronavirus from patients with pneumonia in China, 2019. N Engl J Med. 382 (2020) 727-733.

6. R. Lu, et al, Genomic characterization and epidemiology of 2019 novel coronavirus: implications for virus origins and receptor binding. The Lancet (2020).

7. M. Wang, et al, A precision medicine approach to managing Wuhan Coronavirus pneumonia, Precision Clinical Medicine 3 (2020) 14-21.

8. L. Wenzhong, L. Hualan, COVID-19: Attacks the 1-Beta Chain of Hemoglobin and Captures the Porphyrin to Inhibit Human Heme Metabolism. Chemrxiv (2020) 11938173.

9. T. Mpiana, K.N. Ngbolua, D.S.T. Tshibangu et al, Identification of potential inhibitors of SARS-CoV-2 main protease from Aloe vera compounds: A molecular docking study, Chem. Phys. Lett. 754 (2020) 137751. doi.org/10.1016/j.cplett.2020.137751

10. N. Chen, M. Zhou, X. Dong, J. Qu, F. Gong, Y. Han et al, Epidemiological and clinical characteristics of 99 cases of 2019 novel coronavirus pneumonia in Wuhan, China: a descriptive study. Lancet 395 (2020) 507-13.

11. World Health Organization, Coronavirus disease 2019 (COVID-19) Situation Report - 69 (Report). 29 March 2020. hdl:10665/331615

12. A.J. Rodríguez-Morales, K. MacGregor, S. Kanagarajah, D. Patel, P. Schlagenhauf, Going global Travel and the 2019 novel coronavirus, Travel Med Infect. Dis. 33 (2020) 101578.

13. N. Ngbolua, C.M. Mbadiko, A. Matondo et al, Review on Ethno-botany, Virucidal Activity, Phytochemistry and Toxicology of Solanum genus: Potential Bio-resources for the Therapeutic Management of Covid-19, Eur J Nutrition Food Safety 12 (2020) 35-48. doi.org/10.9734/EJNFS/2020/v12i730246.

14. D.S.T. Tshibangu, A. Matondo, E.M. Lengbiye et al, Possible Effect of Aromatic Plants and Essential Oils against COVID-19 : Review of Their Antiviral Activity, J Complem Altern Medic Res 11 (2020) 1022. doi.org/10.9734/JOCAMR/2020/v11i130175.

15. M. Alfaro, I. Alfaro, C. Angel, Identification of potential inhibitors of SARS-CoV-2 papain-like protease from tropane alkaloids from Schizanthus porrigens: A molecular docking study, Chem. Phys. Lett. 761 (2020) 138068.

16. A. Matondo, J.T. Kilembe, D.T. Mwanangombo et al, Facing COVID-19 via anti-inflammatory mechanism of action: Molecular docking and pharmacokinetic studies of six-anti-inflammatory compounds derived from Passiflora edulis, Research Square (2020). https://doi.org/10.21203/rs.3.rs-87703/v1

17. H. Lu, Drug treatment options for the 2019-new coronavirus (2019-nCoV). Biosci Trends. 14 (2020) 69-71. 
18. L. Zhang, D. Lin, X. Sun, U. Curth, C. Drosten, L. Sauerhering, S. Becker, K. Rox, R. Hilgenfeld, Crystal structure of SARS-CoV-2 main protease provides a basis for design of improved a-ketoamide inhibitors. Science (2020) 409-412.

19. H. Yang, M. Bartlam, Z. Rao, Drug design targeting the main protease, the Achilles' heel of coronaviruses. Curr. Pharm. Des. 12 (2006) 4573-4590.

20. R.K. Ganjhu, P.P. Mudgal, H. Maity, D. Dowarha, S. Devadiga, S. Nag, G. Arunkumar, Herbal plants and plant preparations as remedial approach for viral diseases. Virus disease 26 (2015) 225-36

21. R.R. Narkhede, A.V. Pise, R.S. Cheke, et al, Recognition of Natural Products as Potential Inhibitors of COVID-19 Main Protease (Mpro): In-Silico Evidences. Nat. Prod. Bioprospect. 17 (2020) 1-10.

22. A. Onguéné et al, The potential of anti-malarial compounds derived from African medicinal plants. Part I: Anpharmacological evaluation of alkaloids and terpenoids. Malaria Journal 13 (2013) 449.

23. M.H. Nkunya, J.J. Makangara, S.A. Jonker, Prenylindoles from Tanzanian Monodora and Isolona species. Nat Prod Res. 18 (2004) 253-258.

24. M.R. Cao, M. Tits, L.M. Angenot, M. Frédérich, 17-0-acetyl, 10-hydroxycorynantheol, a selective antiplasmodial alkaloid isolated from Strychnos usambarensis leaves. Planta Med. 77 (2011) 20502053.

25. G. Bidla, V.P. Titanji, B. Joko, G.E. Ghazali, A. Bolad, K. Berzins, Antiplasmodial activity of seven plants used in African folk medicine. Ind J Pharmacol. 36 (2004) 245-266.

26. O.O. Odebiyi, E.S. Sofowora, Antimicrobial alkaloids from a Nigerian chewing stick (Fagara zanthoxyloides). Planta Med. 36(1979) 204.

27. C.O. Okunji, M.M. Iwu, Y. Ito, P.L. Smith, Preparative separation of indole alkaloids from the rind of Picralima nitida (Stapf) T. Durand \& H. Durand by $\mathrm{pH}$ zone refining countercurrent chromatography. J Liquid Chromatogr Relat Technol. 28 (2005) 775-783.

28. M. Frédérich, M.P. Hayette, V. Brandt, J. Penelle, P.G. et al, 10'-hydroxyusambarensine, a new antimalarial bisindole alkaloid from the roots of Strychnos usambarensis. J Nat Prod. 62 (1999) 619.

29. G. Bringmann, F. Teltschik et al, Ancistrobertsonines B, C, and D as well as 1,2didehydroancistrobertsonine D from Ancistrocladus robertsoniorum. Phytochemistry 52 (1999) 321332.

30. G. Bringmann, M. Dreyer et al, Ancistrotanzanine $C$ and related 5,1- and 7,3-coupled naphthylisoquinoline alkaloids from Ancistrocladus tanzaniensis. J Nat Prod. 67 (2004) 743-748.

31. G. Bringmann, K. Messer et al, Habropetaline A, an antimalarial naphthylisoquinoline alkaloid from Triphyophyllum peltatum. Phytochemistry. 62 (2003) 345-349.

32. G. Bringmann, W. Saeb et al, 5-O-demethyldioncophylline A, a new antimalarial alkaloid from Triphyophyllum peltatum. Phytochemistry 49 (1998)1667-1673.

33. G. Bringmann, M. Rübenacker, J.R. Jansen, D. Scheutzow, On the structure of the Dioncophyllaceae alkaloids dioncophylline A ("triphyophylline") and "O-methyltriphyophylline. Tetrahedron Lett 31 (1990) 639-642. 
34. G. Bringmann, M. Rübenacker, R. Weirich, L. Aké Assi, Dioncophylline $C$ from the roots of Triphyophyllum peltatum, the first 5,19-coupled Dioncophyllaceae alkaloid. Phytochemistry 31 (1992) 4019-4024.

35. O. Trott, J. Arthur, AutoDock Vina: improving the speed and accuracy of docking with a new scoring function, efficient optimization and multithreading. J Comput Chem 31 (2010) 455-461.

36. Daina, M. Olivier, V. Zoete, SwissADME: a free web tool to evaluate pharmacokinetics, drug likeness and medicinal chemistry friendliness of small molecules. Sci. Rep. 7 (2017) 42717.

37. K. Lee, G.S. Chang, I.H. Lee, J.E. Chung, K.Y. Sung, K.T. No, The preADME: PCbased program for batch prediction of ADME properties, EuroQSAR 9 (2004) 5-10.

38. L.Verdonk, J. Cole, M. Hartshorn, C. Murray, R. Taylor, Improved protein-ligand docking using GOLD. Proteins 52 (2003) 609-623.

39. Selvaraj, S. Antony, S. Hakdong, Anti-methanogenic effect of rhubarb (Rheum spp.)-An in silico docking studies on methyl-coenzyme M reductase (MCR). Saudi Journal of Biological Sciences 26 (2019) 1458-1462.

40. S. Biovia, Discovery studio visualizer, vol. 936, San Diego, CA, USA, 2017.

41. O. Olubiye, M. Olagunju, M. Keutmann, J. Loschwitz, B. Strodel, High throughput virtual screening to Discover Inhibitors of the Main Protease of the Coronavirus SARS-CoV-2, Molecules 25 (2020) 3193.

42. K. Enmozhi, K. Raja, I. Sebastine, J. Joseph, Andrographolide as a potential inhibitor of SARS-CoV-2 main protease: an in silico approach, J Biomol Struct Dyn (2020) 1-7.

43. O.E. Kasende, A. Matondo, J.T. Muya, S. Scheiner, Interaction between temozolomide and HCl: preferred binding sites, Comput. Theor. Chem. 1075 (2016) 82-86. doi.org/10.1016/j.comptc.2015.11.017

44. E. Kasende, A. Matondo, J.T. Muya, S. Scheiner, Interactions between temozolomide and guanine and its S and Se-substituted analogues, Int. J. Quantum Chem. 117 (2017) 157-169. doi.org/10.1002/qua.25294

45. E. Kasende, V.P.N. Nziko, S. Scheiner, H-Bonding and Stacking Interactions between Chloroquine and Temozolomide, Int. J. Quantum Chem. 116 (2016) 1196. doi.org/10.1002/qua.25152

46. Lagorce, D. Douguet, M.A. Miteva, B.O.Villoutreix, Computational analysis of calculated physicochemical and ADMET properties of protein-protein interaction inhibitors, Sci. Rep. 7 (2017) 46277.

47. C. Martin, A bioavailability score, J. Med. Chem. 48 (2015) 3164-3170.

\section{Table 2}

Due to technical limitations, Table 2 is only available as a download in the supplemental files section

\section{Figures}




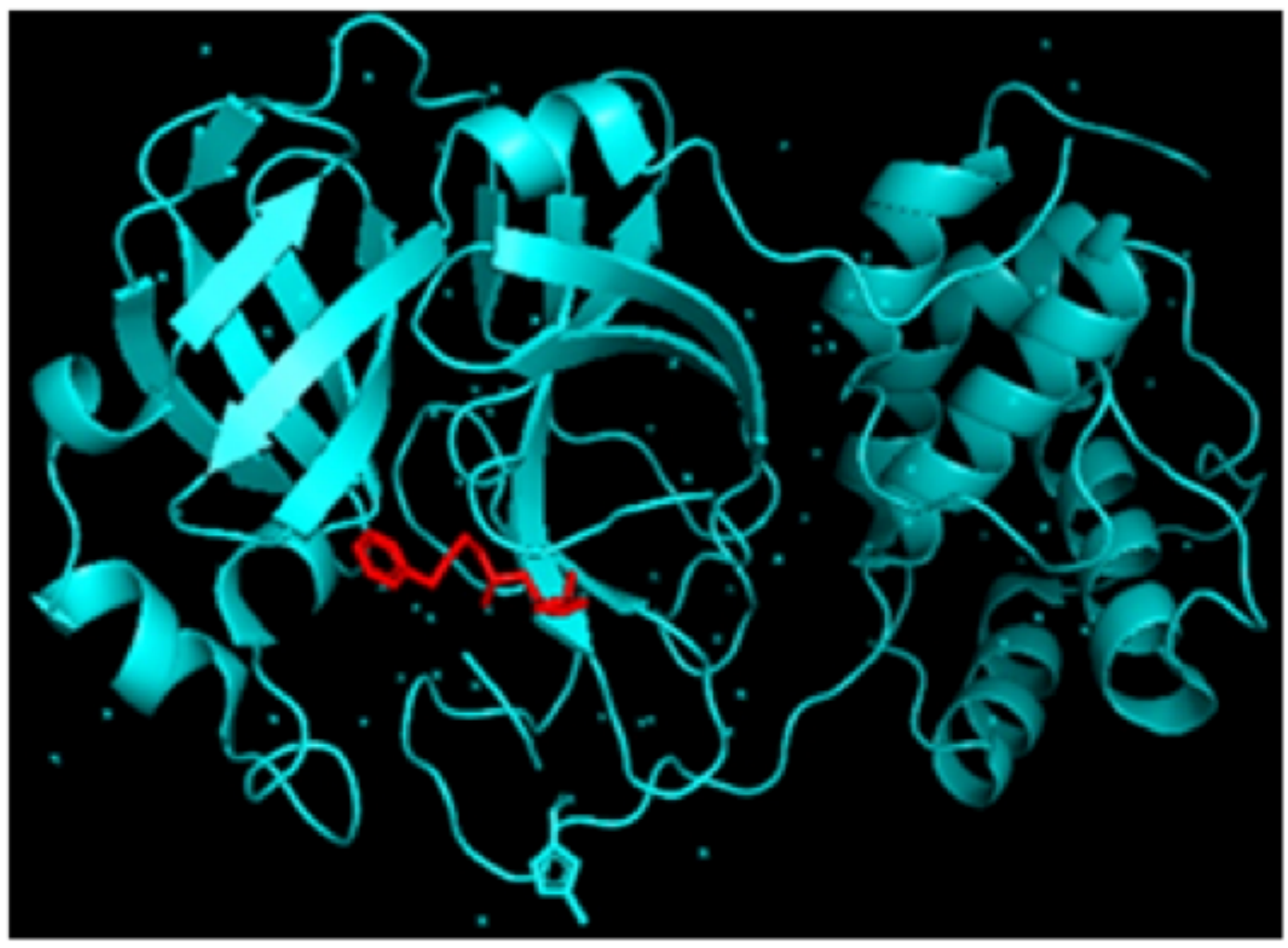

\section{Figure 1}

The crystal structure of COVID-19 main protease in complex with the crystallized inhibitor N3 
<smiles>CC(C)=CCc1ccc2c(c1)NC(=O)C2</smiles>

6-(3-Methylbut-2-enyl)-1,3-dihydroindol-2-one (1)<smiles>CC(C)=CCc1ccc2cc[nH]c2c1</smiles>

6-(3-Methyl-2-butenyl)-1H-indole (4)<smiles>C=CC(C)(C)c1c[nH]c2cc(CC=C(C)C)ccc12</smiles>

Caulidine A (7)<smiles>COc1cc2c(cc1OC)-c1cc3ccc(OC)c(OC)c3c[n+]1CC2</smiles>

Palmatine (10)<smiles></smiles>

Alstonine (13)<smiles>C=CC(C)(C)c1c[nH]c2cc(/C=C/C(C)=O)ccc12</smiles>

Caulidine B (8)<smiles>COc1cc2c(cc1O)CCN1[N+]=Cc3c(ccc(OC)c3OC)C=C21</smiles><smiles></smiles>

Strychnopentamine (14)<smiles>CC(=O)c1ccc2[nH]ccc2c1</smiles>

1H-indole-5-carbaldehyde (3)

3-Geranylindole (6)<smiles>C=CC1CN2CCc3c([nH]c4ccc(O)cc34)C2CC1(C)CCOC(C)=O</smiles>

17-0-acetyl,10-hydroxycorynantheol (9)<smiles>COc1cc2c(cc1O)C=CC1=CC(=[N+]2C)c2cc(OC)c(OC)cc21</smiles>

Fagaronine (12)

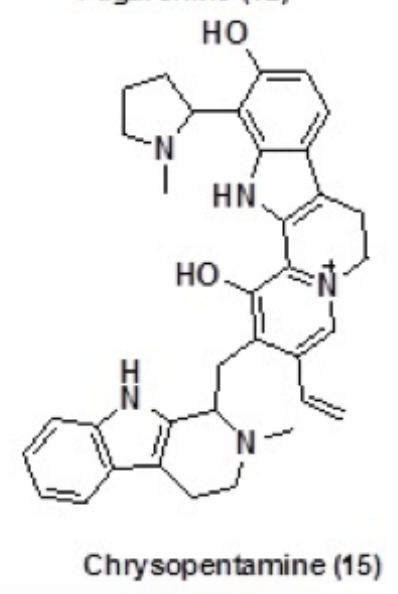

\section{Figure 2}

Indole alkaloids derived from the African flora. 
<smiles></smiles>

Ancis trobrevine (16)<smiles></smiles>

Ancistroberts onine C (19)<smiles>COC1=CC(OC)=C2C(c3c(C)cc(OC)c4c3CC(C)N=C4C)=c3cccc(OC)c3=C12</smiles>

O-methylancistrocladinine (22)<smiles>COc1ccc(OC)c2c(-c3ccc4c(c3O)C(C)NC(C)C4)c(O)cc(OC)c12</smiles>

Habropetaline A (25)<smiles></smiles>

Dioncophylline B (28)<smiles></smiles>

Ancistrobertsonine A (17)<smiles>COc1c(-c2c(O)cc(OC)c3c(OC)cccc23)c(C)cc2c1C(C)NC(C)C2</smiles>

Ancistrobertsonine D (20)<smiles>COC1=CC(OC)=C2C(c3c(C)cc(OC)c4c3CC(C)N(C)C4C)=c3cccc(OC)c3=C12</smiles>

5,1 - O,N-dimethylancis trocladine (23)<smiles>COc1cc(C)c(-c2ccc3c(c2O)C(C)NC(C)C3)c2cccc(O)c12</smiles>

5'-O-Demethyl-dioncophy lline A (26)<smiles>COC1=CC(C)=C2C(c3ccc(O)c4c3CC(C)NC4C)=c3cccc(O)c3=C12</smiles>

Dioncophylline C (29)<smiles>COC1=CC(OC)=C2C(c3c(C)cc(OC)c4c3CC(C)N(C)C4C)=c3cccc(OC)c3=C12</smiles>

Ancistroberts onine B (18)<smiles>COc1cc2c(c(OC)c1-c1c(C)cc3cccc(OC)c3c1OC)C(C)N(C)C(C)C2</smiles>

Ancistrotanzanine C (21)<smiles>COc1cc2c(c(O)c1-c1c(C)cc3cccc(OC)c3c1OC)C(C)N(C)C(C)C2</smiles>

Ancistrotectorine (24)<smiles>COc1cccc2c(-c3ccc4c(c3O)C(C)NC(C)C4)c(C)cc(OC)c12</smiles>

Dioncophylline A (27)<smiles>COc1cc(CO)c(-c2ccc3c(c2O)C(C)NC(C)C3)c2cccc(O)c12</smiles>

Dioncopeltine A (30)

\section{Figure 3}

Naphthoisoquinolines derived from plants used in African traditional medicine

\section{Supplementary Files}

This is a list of supplementary files associated with this preprint. Click to download. 
- TungaetalSuppllnformat.docx

- Table2.docx 